\title{
Review: Pharmacotherapy for smoking cessation
}

\author{
Chok Limsuwat MD, Shigeki Saito MD, MSCR, Karin Halvorson MD
}

\begin{abstract}
Smoking is associated with numerous cancers and atherosclerosis. Smoking cessation has substantial potential in reducing morbidity and mortality worldwide. The initial steps " 5 A's" (Ask, Advise, Assess, Assist, Arrange) should be applied in all patients. Behavioral counseling and pharmacotherapy are both effective, but the combination of the two is more effective than either alone. The first-line pharmacotherapy includes nicotine replacement, bupropion, and varenicline. Nicotine replacement therapy (NRT) consists of long-active formulations, such as in a patch, and short-acting formulations such as in gum, lozenge, inhaler, and nasal spray. As compared to placebo, NRT increases the chances of quitting smoking. Nicotine replacement therapy does not increase cardiovascular risk and is safe in patients with cardiovascular disease. Sustained-release bupropion is more effective than nicotine patches and can be combined with nicotine patches. Buprenorphine is generally well tolerated, except that it lowers seizure threshold and is contraindicated in patients with seizure disorders. Varenicline also significantly improves the success rate of smoking cessation. The latest evidence suggests that varenicline is not associated with an increased risk of neuropsychiatric or cardiovascular events. In conclusion, the use of NRT (nicotine patch + nicotine gum/lozenge/inhaler/spray), bupropion (with NRT), or varenicline is strongly recommended for smoking cessation, unless they are contraindicated.
\end{abstract}

Keywords: smoking cessation; nicotine replacement therapy; varenicline; bupropion: e-cigarettes

\section{INTRODUCTION}

Based on data from the 2016 National Health Interview Survey (NHIS), the prevalence of current cigarette smoking among U.S. adults declined from $24.7 \%$ in 1997 to $15.3 \%$ in 2015 . Data for the first half of 2016 identify no significant change; it was estimated that about $16 \%$ of U.S. adults were current cigarette smokers. ${ }^{1}$ Smoking is the leading cause of preventable premature morbidity and mortality worldwide, and smoking cessation reduces

Corresponding author: Chok Limsuwat

Contact Information: Chok.limsuwat@gmail.com

DOI: $10.12746 /$ swrccc.v6i25.481 the number of smokers who develop and die from smoking related diseases. ${ }^{2-4}$ Approximately $19 \%$ of U.S. smokers want to quit and have tried to do so, but only $6 \%$ of those who tried to quit had sustained abstinence from smoking one year later. ${ }^{5}$ The majority of attempts to quit fail within the first week, ${ }^{6}$ and two-thirds of smokers use no pharmacologic treatment when trying to quit. ${ }^{2}$

This review provides an overview on smoking cessation approaches, with the main focus on pharmacotherapy.

\section{SMOKING CESSATION APPROACH}

Smoking cessation can be complicated and needs a team-based approach to increase the success rate. 
"Five A's" are generally recommended: Ask about smoking, Advise them to quit, Assess willingness to quit smoking within next 30 days, Assist by providing aids to quit smoking, and Arrange a follow up and contact person. ${ }^{7}$

The two main approaches to assist smoker who are ready to quit are behavioral support and pharmacotherapy. Behavioral therapy aims to boost or support motivation to resist the craving to smoke as well as to develop the capacity to implement plans to avoid smoking. Group support and telephone counseling quit lines are also available in the U.S. Pharmacotherapy aims to reduce the intensity of urges to smoke and/or ameliorate the aversive symptoms.

\section{Pharmacotherapy}

Most smokers show symptoms of addiction to nicotine such as tolerance and nicotine withdrawal symptoms. ${ }^{8}$ Nicotine withdrawal usually peaks within a few days and lasts for a few weeks. ${ }^{9}$ Withdrawal symptoms include increased appetite, weight gain, insomnia, irritability, anxiety, inability to concentrate, and restlessness. Pharmacotherapy has an important role to reduce these symptoms. Ideal drugs are the ones that both block the addictive effect of nicotine and prevent or reduce the development of withdrawal symptoms with minimal side effects.

The Food and Drug Administration (FDA) has approved three first-line medications for smoking cessation: nicotine replacement therapy (NRT), varenicline, and bupropion (see doses, duration, and efficacy in the Table). ${ }^{7}$ Pharmacotherapy is not recommended for pregnant smokers (insufficient evidence of effectiveness [the Cochrane Rev 2014 suggests the pharmacotherapy is also effective in this population but the effect size appears small.]), smokeless tobacco users (no FDA indication for smokeless tobacco cessation), and individuals smoking fewer than 10 cigarettes per day. Nonprescription sales of NRT products are restricted to adults, and NRT use in minors requires a prescription.

\section{NICOTINE REPLACEMENT THERAPY}

The aim of NRT is to provide nicotine replacement, decrease the urge of withdrawal symptoms, and break the smoking habit. In the U.S., nicotine patches, lozenges, and gum are available without a prescription. However, nasal spray and oral inhalers are available by prescription only. A long acting preparation (e.g., patch) is the primary NRT to control baseline nicotine withdrawal symptoms. A short onset form of NRT (e.g., lozenge, gum, inhaler, or nasal spray) helps to control urges and withdrawal symptoms on an as needed basis. ${ }^{10}$ Overall, treatment with single NRT increases quit rate to about two-fold as compared with placebo. ${ }^{11-13}$ There are no differences in efficacy between the patch, inhaler, nasal spray, and gum. ${ }^{14}$ However, a combination of long acting and short-acting NRT improves the success rate compared with single NRT. ${ }^{15}$

Common side effects include headache, nausea, vomiting, abdominal pain, and diarrhea. ${ }^{16} \mathrm{NRT}$ is relatively safe to use in the normal population and is not associated with an increased risk of adverse cardiovascular events in the first year after acute coronary syndrome. $^{17}$

\section{BUPROPION}

Bupropion is an anti-depressant that is a neuronal reuptake inhibitor of dopamine and noradrenaline. It was observed that patients treated with this medication spontaneously stopped smoking. For smoking cessation, only the sustained released (SR) form has been studied and is licensed. At the end of a seven-week study, the rates of smoking cessation were $19.0 \%$ in the placebo group, $28.8 \%$ in the $100-m g$ group, $38.6 \%$ in the $150-\mathrm{mg}$ group, and $44.2 \%$ in the $300-\mathrm{mg}$ group $\left(P\right.$ 0.001). ${ }^{18}$ Later data from Cochrane Systematic Reviews also suggest that bupropion SR significantly increases the likelihood of smoking cessation (relative risk [RR] of 1.6 ; $95 \%$ confidence interval [Cl] 1.49 to 1.76). ${ }^{19}$ This medication is available in oral form and should be continued for at least 12 weeks and may be continued longer in special cases. A randomized control trial compared a placebo, bupropion, nicotine patch, and bupropion plus a nicotine patch. Results 
Table. FDA approved pharmacotherapy for smoking cessation

\begin{tabular}{|c|c|c|c|}
\hline Medications & $\begin{array}{l}\text { Drug vs } \\
\text { placebo } \\
\text { OR }(95 \% \text { CI })\end{array}$ & Strength and dosing ${ }^{40-42}$ & Side effects Precautions \\
\hline $\begin{array}{l}\text { Nicotine } \\
\text { replacement }{ }^{43,44}\end{array}$ & & & Safe for CVD and COPD \\
\hline Patch & $1.64(1.52-1.78)$ & $\begin{array}{l}7,14,21 \mathrm{mg} / 24 \mathrm{hr} \\
21 \mathrm{mg} \text { for }>10 \text { cigarettes/day } \\
14 \mathrm{mg} \text { for } \leq 10 \text { cigarettes/day } \\
7 \mathrm{mg} \text { used when tapering }\end{array}$ & $\begin{array}{l}\text { Skin irritation, insomnia, } \\
\text { vivid dreams }\end{array}$ \\
\hline Gum & $1.49(1.40-1.60)$ & $\begin{array}{l}2 \mathrm{mg}, 4 \mathrm{mg} \\
\text { The } 4 \text {-mg strength should be used by patients } \\
\text { who smoke } 25 \text { or more cigarettes a day. } \\
\text { Wks } 1 \text { to } 6 \text { : one piece every } 1-2 \mathrm{hr} \text {; ws } 7 \text { to } 9 \text { : } \\
\text { one piece every } 2-4 \mathrm{hr} \text {; wks } 10 \text { to } 12 \text { : one piece } \\
\text { every } 4-8 \mathrm{hr} \\
\text { Do not use more than } 24 \text { pieces a day. } \\
\text { Do not eat or drink before or while using } \\
\text { nicotine gum / lozenges, because their } \\
\text { effectiveness may be reduced by some foods } \\
\text { and beverages. }\end{array}$ & $\begin{array}{l}\text { Mouth irritation, jaw } \\
\text { soreness, heartburn, hiccups, } \\
\text { or nausea (gastrointestinal } \\
\text { side effects usually due to } \\
\text { overly vigorous chewing) }\end{array}$ \\
\hline Lozenge & $1.95(1.61-2.36)$ & $\begin{array}{l}2 \mathrm{mg}, 4 \mathrm{mg} \\
\text { The } 4-\mathrm{mg} \text { strength should be used by patients } \\
\text { who smoke } 25 \text { or more cigarettes a day } \\
\text { Wks } 1 \text { to } 6 \text { : one piece every } 1-2 \mathrm{hr} \text {; wks } 7 \text { to } 9 \text { : } \\
\text { one piece every } 2-4 \mathrm{hr} \text {; wks } 10 \text { to } 12 \text { : one piece } \\
\text { every } 4-8 \mathrm{hr}\end{array}$ & $\begin{array}{l}\text { Mouth irritation, hiccups, } \\
\text { heartburn, or nausea }\end{array}$ \\
\hline Inhaler & $1.90(1.362 .67)$ & $\begin{array}{l}10 \mathrm{mg} \text { per cartridge } \\
\text { Inhale as needed (every one to two hours) } \\
\text { Maximum: } 16 \text { cartridges/day }\end{array}$ & $\begin{array}{l}\text { Mouth and throat irritation } \\
\text { Caution in reactive airway } \\
\text { disease }\end{array}$ \\
\hline Nasal Spray & $2.02(1.492 .73)$ & $\begin{array}{l}0.5 \mathrm{mg} \text { per spray }(10 \mathrm{mg} / \mathrm{mL}) \\
\text { Apply one spray to each nostril every one to } \\
\text { two hours } \\
\text { Maximum: } 10 \text { sprays/hour } 80 \text { sprays/day }\end{array}$ & $\begin{array}{l}\text { Nasal and throat irritation, } \\
\text { rhinitis, sneezing, cough, or } \\
\text { teary eyes }\end{array}$ \\
\hline Varenicline $^{15}$ & $2.27(2.02-2.55)$ & $\begin{array}{l}0.5,1 \mathrm{mg} \text { tablets } \\
0.5 \mathrm{mg} \text { by mouth in the morning for } 3 \text { days. } \\
\text { Increase to } 0.5 \mathrm{mg} \text { by mouth twice daily for } \\
4 \text { days. Then, increase to } 1 \mathrm{mg} \text { by mouth twice } \\
\text { daily. Quit smoking on Day } 8 \text {. Maintenance up } \\
\text { to } 6 \text { months }\end{array}$ & $\begin{array}{l}\text { Nausea, insomnia, abnormal } \\
\text { dreams, headache, skin rash } \\
(\leq 3 \%)\end{array}$ \\
\hline Bupropion $^{15}$ & $1.69(1.53-1.85)$ & $\begin{array}{l}150-\mathrm{mg} \text { sustained release tablets } \\
150 \mathrm{mg} \text { by mouth in the morning for } 3 \text { days, } \\
\text { then increase to } 150 \mathrm{mg} \text { by mouth twice daily. } \\
\text { Maintenance up to } 6 \text { months }\end{array}$ & $\begin{array}{l}\text { Decreased seizure threshold } \\
\text { Insomnia, agitation, dry } \\
\text { mouth, headache }\end{array}$ \\
\hline
\end{tabular}


showed bupropion alone or in combination with a nicotine patch resulted in higher long-term abstinence rates than did the use of placebo or a nicotine patch alone $(P<0.0001)$. Treatment with both bupropion and the nicotine patch was not significantly better than treatment with bupropion alone either at the end of the treatment period or during follow-up. Weight gain at seven weeks was significantly less in the combined treatment group than in the bupropion group and the placebo group $(\mathrm{P}<0.05) .{ }^{20}$

The most common side effects are insomnia, dry mouth, and headache, similar to other anti-depressant medications. This medication is safe for patients with cardiovascular disease (CVD) as well as COPD. Previously, there was a concern that bupropion may increase suicidal behavior and self-injury. However, a randomized trial comparing varenicline, bupropion, NRT, and placebo found no difference in neuropsychiatric adverse events among the treatment group.11 Bupropion is contraindicated in patients with a seizure disorder or predisposition to seizure, because it reduces the seizure threshold. ${ }^{21}$

\section{VARENICLINE}

Varenicline is thought to act as a partial agonist against alpha4 beta2 subunit of nicotinic acetylcholine receptor. ${ }^{22}$ The duration of initial varenicline treatment is about 12 weeks but may need to extend longer. The dose needs to be adjusted for renal impairment; dose adjustment for hepatic impairment is not necessary because there is no hepatic excretion. A meta-analysis of randomized trials showed that varenicline was more effective than placebo and almost triples the chance of stopping smoking (Odd ratio [OR] 2.88; $95 \% \mathrm{Cl} 2.40$ to 3.47 ). ${ }^{15}$

Varenicline is generally safe. Frequently reported adverse events include nausea, insomnia, abnormal dreams, visual disturbances, syncope, and moderate to severe skin reactions. Meta-analysis data suggest that varenicline can be safely combined with NRT; outcomes were favorable for combination therapy for quitting smoking for early and late outcomes $(\mathrm{OR}=1.50,95 \% \mathrm{Cl} 1.14$ to 1.97 ; OR=1.62, $95 \% \mathrm{Cl} 1.18$ to 2.23 , respectively). ${ }^{23}$ Although this combination is not yet widely used or strongly recommended, it can be considered in some patients.

In 2009, the FDA added a "black box" warning about potential neuropsychiatric side effects on this medication, but this warning was removed in 2016 based on results of a randomized trial that found no difference in adverse neuropsychiatric events comparing varenicline with a nicotine patch or placebo in patients with or without a coexisting psychiatric disorder. ${ }^{11}$

In 2011, an FDA advisory that varenicline may increase the risk of cardiovascular events in patients with known CVD was based upon the findings from a randomized trial in 714 smokers with stable CVD. ${ }^{24}$ However, in 2016 subsequent meta-analysis found no evidence that varenicline increases the rate of serious cardiovascular adverse events. Results were similar among those with and without cardiovascular disease, and the American Heart Association recommend continuing this medication for smoking cessation in patients with CVD. ${ }^{25}$

\section{OTHER PHARMACOTHERAPY TREATMENT}

Electronic cigarettes (ECs) are electronic devices that heat a liquid into an aerosol for inhalation. The liquid is usually comprised of propylene glycol and glycerol, with or without nicotine and flavors. The use of ECs has dramatically increased in popularity in numerous countries.

In 2015, the U.S. Preventive Services Task Force stated that there is insufficient evidence to recommend ECs for smoking cessation. There has been conflicting and limited evidence, and early studies suffer from small sample sizes, the lack of control groups, and significant loss to follow-up. A recent meta-analysis showed that those who used ECs were less likely to quit smoking. ${ }^{26,27}$ However, some data suggest that switching from combustible to aerosolized nicotine, while it may not result in smoking cessation per se, may result in decreased morbidity and mortality.

The Center for Disease Control and Prevention states that ECs may lead to public health benefit if individual adult smokers switch completely from combustible tobacco products to EC and, furthermore, if their 
use assists in a rapid transition to a society with little or no combustible tobacco use. ${ }^{28}$ More randomized trials are needed with long-term data about the efficacy and safety of ECs. ${ }^{29}$

Cytisine is a plant derivative that has partial agonist activity against the alpha4 beta2 nicotinic acetylcholine receptor, similar to varenicline. ${ }^{22}$ Although it has been used in Eastern Europe for smoking cessation for decades, it is not available in North America. ${ }^{30}$ Metaanalysis concluded that cytisine is effective for smoking cessation with an efficacy comparable to other current licensed treatments. The pool data comparison between cytisine and placebo showed a RR to quit smoking of $1.57(95 \% \mathrm{Cl} 1.42$ to 1.74$){ }^{31}$

Apomorphine is an aporphine derivative dopaminergic agonist with an extensive and varied history of medical applications. This medication works on the alternate serotonin pathway and may be an effective method for smoking cessation by decreasing drug-seeking behaviors. ${ }^{32}$ However, there is still a lack of strong evidence for this pharmacotherapy.

Nortriptyline is a tricyclic anti-depressant. A metaanalysis of six randomized trials found that nortriptyline increased the likelihood of abstinence (RR 2.03, 95\% Cl 1.482.78). ${ }^{19}$ Patients receiving nortriptyline were more likely to report side effects including dry mouth and sedation. ${ }^{19}$

\section{NON-PHARMACOTHERAPY}

Behavioral therapy (BT) may increase cessation rates by enhancing motivation to stop smoking and supporting people's capacity to avoid smoking in the face of urges to smoke. Behavioral therapy could be started by the "Five A's" questions approach. Behavioral support should include specialty clinics or smoking cessation programs, telephone counseling, mobile phone applications, and Internet-based interventions for smoking cessation. Together they seem to improve smoking cessation rates. ${ }^{33-36}$

Other smoking cessation methods, which do not have enough evidence to recommend them, include acupuncture ${ }^{37}$ hypnosis, ${ }^{38}$ and financial incentives. ${ }^{39}$

\section{COMBINATION OF PHARMACOTHERAPY AND NON-PHARMACOTHERAPY}

The most recent meta-analysis demonstrated that combination therapy among varenicline, bupropion, and NRT might be less effective than previously thought. The statistical analysis from this study showed varenicline with $\mathrm{BT}$ increased abstinence more than other combinations (varenicline versus bupropion: $\mathrm{OR}=1.56$; varenicline versus nicotine patch: $\mathrm{OR}=1.65$; varenicline versus short-acting nicotine-replacement therapies: OR $1=1.68) \cdot{ }^{35}$ The combination of a nicotine patch and a short-acting NRT should be recommended over a single NRT due to a higher rate of quitting smoking (OR 1.34). ${ }^{15}$ Currently, there is insufficient evidence to recommend combination pharmacotherapies that include both bupropion and varenicline. ${ }^{15,35}$

\section{Conclusion}

All smokers should be evaluated for smoking cessation with the "Five A's" questions and should be advised to quit smoking. Smoking cessation should be managed with a combination of behavioral therapy and pharmacotherapy, which produces higher rates of smoking cessation than either alone.

Article citation: Limsuwat C, Saito S, Halvorson K. Review: pharmacotherapy for smoking cessation. The Southwest Respiratory and Critical Care Chronicles 2018;6(24):31-37

From: Pulmonary Diseases, Critical Care Medicine, and Environmental Medicine, Tulane University Health Sciences Center, New Orleans, LA (CL, SS, KH); Emergency Medicine Department, Faculty of Medicine Siriraj Hospital, Mahidol University, Bangkok, Thailand (CL); Pulmonary Disease, Bumrungrad International Hospital, Bangkok, Thailand (CL)

Submitted: $4 / 2 / 2018$

Accepted: 6/17/2018

Reviewer: Susan Hendrick PhD

Conflicts of interest: none

This work is licensed under a Creative Commons Attribution-ShareAlike 4.0 International License 


\section{REFERENCES}

1. Early Release of Selected Estimates Based on Data From the January-June 2016 National Health Interview Survey. (Accessed January 20, 2017, at http:/www.cdc.gov/nchs/ nhis/releases/released201611.htm.)

2. Rigotti NA. Strategies to help a smoker who is struggling to quit. JAMA 2012;308:1573-80.

3. Anthonisen NR, Skeans MA, Wise RA, et al. The effects of a smoking cessation intervention on 14.5-year mortalityA randomized clinical trial. Annals of internal medicine 2005; 142:233-9.

4. Jha P, Landsman V, Rostron B, et al. 21st-century hazards of smoking and benefits of cessation in the United States. New Engl J Med 2013;368:341-50.

5. Centers for Disease C, Prevention. Quitting smoking among adults-United States, 2001-2010. MMWR Morbidity Mortality Weekly Report 2011;60:1513-9.

6. Hughes JR, Keely J, Naud S. Shape of the relapse curve and long-term abstinence among untreated smokers. Addiction 2004;99:29-38.

7. Fiore $\mathrm{MC}$, Jaen $\mathrm{CR}$, Baker TB, et al. A clinical practice guideline for treating tobacco use and dependence: 2008 Update-A US Public Health Service report. Am J Prev Med 2008;35:158-76.

8. Breslau N, Kilbey MM, Andreski P. DSM-III-R nicotine dependence in young adults: prevalence, correlates and associated psychiatric disorders. Addiction 1994;89:743-54.

9. Hughes JR. Effects of abstinence from tobacco: valid symptoms and time course. Nicotine \& Tobacco Research: official journal of the Society for Research on Nicotine and Tobacco 2007;9:315-27.

10. Hartmann-Boyce J, Aveyard P. Drugs for smoking cessation. BMJ 2016;352:i571.

11. Anthenelli RM, Benowitz NL, West R, et al. Neuropsychiatric safety and efficacy of varenicline, bupropion, and nicotine patch in smokers with and without psychiatric disorders (EAGLES): a double-blind, randomised, placebo-controlled clinical trial. Lancet 2016;387:2507-20.

12. Cunningham JA, Kushnir V, Selby P, et al. Effect of mailing nicotine patches on tobacco cessation among adult smokers a randomized clinical trial. JAMA Intern Med 2016;176:184-90.

13. Rigotti NA. Clinical practice. Treatment of tobacco use and dependence. New Engl J Med 2002;346:506-12.

14. Hajek P, West R, Foulds J, et al. Randomized comparative trial of nicotine polacrilex, a transdermal patch, nasal spray, and an inhaler. Archives of internal medicine 1999;159:2033-8.

15. Cahill K, Stevens $S$, Perera R, et al. Pharmacological interventions for smoking cessation: an overview and network meta-analysis. The Cochrane database of systematic reviews 2013:CD009329.

16. Drug, Therapeutics B. Republished: Nicotine and health. BMJ 2014;349:2014 7 0264rep.

17. Woolf KJ, Zabad MN, Post JM, et al. Effect of nicotine replacement therapy on cardiovascular outcomes after acute coronary syndromes. American J Card 2012;110:968-70.

18. Hurt RD, Sachs DP, Glover ED, et al. A comparison of sustained-release bupropion and placebo for smoking cessation. New Engl J Med 1997;337:1195-202.

19. Hughes JR, Stead LF, Hartmann-Boyce J, et al. Antidepressants for smoking cessation. The Cochrane database of systematic reviews 2014:CD000031.

20. Jorenby DE, Leischow SJ, Nides MA, et al. A controlled trial of sustained-release bupropion, a nicotine patch, or both for smoking cessation. New Engl J Med 1999;340:685-91.

21. Wilkes $S$. The use of bupropion $S R$ in cigarette smoking cessation. International J chronic obstructive pulmonary disease 2008;3:45-53.

22. Hays JT, Ebbert JO. Varenicline for tobacco dependence. New Engl J Med 2008;359:2018-24.

23. Chang $\mathrm{PH}$, Chiang $\mathrm{CH}, \mathrm{Ho} \mathrm{WC}$, et al. Combination therapy of varenicline with nicotine replacement therapy is better than varenicline alone: a systematic review and meta-analysis of randomized controlled trials. BMC public health 2015;15:689.

24. FDA revises description of mental health side effects of the stop-smoking medicines Chantix (varenicline) and Zyban (bupropion) to reflect clinical trial findings. (Accessed March 19th, 2017, at http://www.fda.gov/downloads/Drugs/ DrugSafety/UCM532262.pdf.)

25. Sterling LH, Windle SB, Filion KB, et al. Varenicline and adverse cardiovascular events: a systematic review and meta-analysis of randomized controlled trials. J Amer Heart Assoc 2016;5.

26. Kalkhoran S, Glantz SA. E-cigarettes and smoking cessation in real-world and clinical settings: a systematic review and meta-analysis. Lancet Respiratory Med 2016;4:116-28.

27. Farsalinos KE, Polosa R. Safety evaluation and risk assessment of electronic cigarettes as tobacco cigarette substitutes: a systematic review. Therapeutic advances in drug safety 2014;5:67-86.

28. CDC Office on Smoking and Health E-cigarette Information 2015 [Accessed on 18 June 2018]. Available from: https:// www.cdc.gov/tobacco/stateandcommunity/pdfs/cdc-osh-information-on-e-cigarettes-november-2015.pdf.

29. Erratum: Borderud SP, LiY, Burkhalter JE, et al. Electronic cigarette use among patients with cancer: Characteristics of electronic cigarette users and their smoking cessation outcomes. Cancer. doi: 10.1002/ cncr.28811. Cancer 2015;121:800.

30. Zatonski W, Zatonski M. Cytisine versus nicotine for smoking cessation. New Engl J Med 2015;372:1072. 
31. Hajek P, McRobbie H, Myers K. Efficacy of cytisine in helping smokers quit: systematic review and meta-analysis. Tho$\operatorname{rax} 2013 ; 68: 1037-42$.

32. Morales-Rosado JA, Cousin MA, Ebbert JO, et al. A Critical review of repurposing apomorphine for smoking cessation. Assay and drug development technologies 2015;13:612-22.

33. Graham AL, Carpenter KM, Cha $\mathrm{S}$, et al. Systematic review and meta-analysis of Internet interventions for smoking cessation among adults. Substance abuse and rehabilitation 2016;7:55-69.

34. Whittaker R, McRobbie H, Bullen C, et al. Mobile phonebased interventions for smoking cessation. The Cochrane database of systematic reviews 2016;4:CD006611.

35. Windle SB, Filion KB, Mancini JG, et al. Combination therapies for smoking cessation: a hierarchical Bayesian meta-analysis. Am J Prev Med 2016;51:1060-71.

36. Kotz D, Brown J, West R. Prospective cohort study of the effectiveness of smoking cessation treatments used in the "real world". Mayo Clinic Proc 2014;89:1360-7.

37. White AR, Rampes H, Liu JP, et al. Acupuncture and related interventions for smoking cessation. The Cochrane database of systematic reviews 2011:CD000009.
38. Barnes J, Dong CY, McRobbie H, et al. Hypnotherapy for smoking cessation. The Cochrane database of systematic reviews 2010:CD001008.

39. Volpp KG, Troxel AB, Pauly MV, et al. A randomized, controlled trial of financial incentives for smoking cessation. New Engl J Med 2009;360:699-709.

40. Karpinski JP, Timpe EM, Lubsch L. Smoking cessation treatment for adolescents. The journal of pediatric pharmacology and therapeutics: JPPT: the official journal of PPAG 2010;15:249-63.

41. Rigotti NA. Strategies to help a smoker who is struggling to quit. JAMA 2012;308:1573-80.

42. Shahab L, Brose LS, West R. Novel delivery systems for nicotine replacement therapy as an aid to smoking cessation and for harm reduction: rationale, and evidence for advantages over existing systems. CNS drugs 2013; 27:1007-19.

43. Stead LF, Perera R, Bullen C, et al. Nicotine replacement therapy for smoking cessation. The Cochrane database of systematic reviews 2012;11:CD000146.

44. Stead LF, Perera R, Bullen C, et al. Nicotine replacement therapy for smoking cessation. The Cochrane database of systematic reviews 2008:CD000146. 